\title{
Detection of Canine Parvovirus in Diarrheic Dogs in Three Egyptian Provinces During 2019-2020
}

\author{
Norhan El-Sayed Salman ${ }^{1 *}$, Mahmoud, A. ${ }^{2}$, \\ Eman Kamal El-Sayed ${ }^{3}$ and El-Tarabili, M. $^{3}$ \\ ${ }^{1}$ Veterinarian. norhansalman12@gmail.com * corresponding \\ author. ${ }^{2}$ Department of Animal Medicine, Faculty of Veterinary \\ Medicine Suez Canal University, Ismailia, Egypt. \\ ahmedvet_2012@yahoo.com ${ }^{3}$ Department of virology,Faculty of \\ Veterinary Medicine, Suez Canal University, Ismailia, Egypt. \\ vet.emankamal@gmail.com
}

\begin{abstract}
Canine parvovirus (CPV2) is considered one of the serious and problematic diseases in young puppies, it remains a common and vital reason of morbidity and mortality in puppies, with very low survival rates in untreated dogs. It causes hemorrhagic enteritis and myocarditis in affected dogs. CPV2 has three antigenic variants CPV-2a, CPV-2b and $\mathrm{CPV}-2 \mathrm{c}$ - have been described, which are determined by variations at residue 426 of the VP2 capsid protein. The aim of the present study was to detect CPV-2 in feces of clinically diseased diarrheic puppies by rapid Immunochromatographic test (ICT) followed by polymerase chain reaction (PCR). One hundred fecal samples were collected from clinically suspected dogs with CPV-2 in three different provinces and test by ICT then make extraction of DNA and examined by PCR. The clinical diagnosis was confirmed in 45 suspected clinical cases $(45 \%)$ by rapid test (ICT) and $86 \%$ by PCR using common and specific primers sets for detection of CPV2.
\end{abstract}

\section{Keywords:}

Canine parvovirus 2 (CPV2), MVC minute canine virus, Epidemiology, Diagnosis, Treatment, PCR, rapid Immunochromatographic test (ICT).

\section{Introduction}

Canine Parvovirus2 (CPV-2) is a highly contagious virus that affects dogs (Burtonboy et al., 1979), that is causing severe gastrointestinal disease and occasionally cardiac disease. Canine parvovirus2 is transmitted from one dog to another through contact with 
infected faeces (Kramer et al., 1980).

Appel et al. (1979) reported that in the early 1970s, a new infectious disease with a high rate of mortality was observed in puppies through the world, and a novel parvovirus was isolated in both canine and feline cell cultures. The virus was referred to as CPV-2 to distinguish it from the unrelated parvovirus minute virus of canines (MVC or CPV-1).

Wills (1952) mentioned that CPV2 belongs to the genus Protoparvovirus and the family Parvoviridae, has singlestranded DNA negative sense, genome containing two open reading frames (ORFs). The first ORF encodes two nonstructural proteins, NS1 and NS2. The second ORF encodes two structural proteins, VP1 and VP2.

CPV-2 possesses a singlestranded DNA genome of about 5,200 nucleotides in length, enclosed in a 26-nm-diameter icosahedral capsid made up of a combination of two proteins, VP1 and VP2. By sequence analysis, CPV-2 has been shown to be closely related to feline panleukpenia virus, from which it presumably originated, and also to parvoviruses from raccoons, minks, and arctic foxes, all of which are included in the feline parvovirus subgroup (Parrish et al., 1991).
VP1 and VP2 each encode parts of the viral capsid, which is assembled from 54 copies of VP2 and 6 copies of VP1. VP2, the major capsid protein, is also the major antigenic protein and determines viral tissue tropism and host range. NS1, an apheliotropic nuclear phosphoprotein, plays an essential role in viral replication and is responsible for inducing cell apoptosis (McMaster et al. 1981; Trashcan et al. 1982; Reed et al. 1988).

A few years after the emergence of CPV-2, two new antigenic types, designated type $2 \mathrm{a}$ and type $2 b$ and distinguishable by means of monoclonal antibodies (Mabs) (Parrish et al., 1988a). In 2000 in Italy, CPV-2c with (asparagine) Asp426 (glutamic acid) Glu (by the substitution of Glu in lieu of (aspartic acid) Asn or Asp at residue 426 of the capsid protein VP2; therefore, it is also referred to as Glu-426.

\section{Objectives}

This study aimed to detection CPV2 in diarrheic dogs in different three provinces in the period 2019 to 2020.

\section{Mate rial and Methods}

A total number of $100 \mathrm{of}$ fecal samples from 7 breeds of nonvaccinated puppies (79male and 21 female) aged between (1.5-6) month these puppies suffered from severe hemorrhagic diarrhea, vomiting. these samples collected from 3 
different provinces (30 samples from Ismailia, 30 samples from Al-Gharbiuh and 40 Samples from El-behaira for detection and Molecular characterization of CPV2. (De la Torre D et al., 2018).

Rapid test for detection of CPV2 in feces; Quicking canine parvovirus Ag test from Quicking Biotech Company, Egypt. It used according the instruction of the manufactures.

DNA extraction kits DNA was extracted using ABT DNA Mini extraction kit (spin column) from ABT applied Biotechnology Company, Egypt. according to the protocol of the manufacturer.

PCR master mix kit Master mix from applied biotechnology Co, LTD, Egypt according to the protocol of the Manufacture instructions.

Materials used for conventional PCR; aOligonucleotide primers pair of oligonucleotide primers was chosen to amplify the mutation in residue 426 of the VP2 gene. Sequence of the primer as follow ; ( VP2-F 5AGCAGATGGTGATCCAAG AT-3), and (VP2-R5 TGGATTCC AAGTGAGAGG3). Using this pair of oligonucleotide primers yields 529bp PCR products specific for CPV-VP2 (residue 426). (De la Torre $D$ et al., 2018). From applied biotechnology Co, IID,
Egypt. PCR product of CPV VP2 was electrophoresed in agrose gel to visualize the predicted band. In Agrose gel was prepared as $1 \%$ agrose in Tris acetic EDTA buffer, Ethedium bromide stain was added at final concentration of $0.5 \mu \mathrm{g} \backslash \mathrm{ml}$ to stain the predicted band.

b-DNA Ladder composed of cloned and purified 12 DNA band of molecular weight. It from applied biotechnology company used according to manufacturer instructions.

\section{Results}

\section{1-Rapid}

\section{Immunochromatographic}

test: A total 100 fecal samples from diseased were examined for detection of CPV-2(Ag) by rapid Immunochromatographic test (ICT) (fig1).

Examination Revealed the number of positive samples for ICT from total number of current diseased dog in different localities as follow: 45samples out of 100samples are positive to CPV2from diseased dog representing $45 \%$.

2. Molecular diagnosis of CPV2 by PCR:

A total 100 fecal samples were examined by conventional PCR and gel electrophoresis (fig2) for detection of CPV2 DNA using specific set of forward and reverse primer for VP2 capsid protein. 86 out of 100 samples from diseased dog $(86 \%)$ give 
predicted bands in agrose gel at $\mathbf{5 2 9}$ bp to CPV2 with total percentage of 86 .

Furthermore, Comparison between

Immunochromatographic test ICT and PCR for diagnosis of CPV2 showed in (table 2) that the molecular diagnosis of
CPV2 by PCR give high percentage than rapid ICT diagnosis with $86 \%$ for PCR and $45 \%$ for rapid ICT. Meanwhile Rapid test is lower sensitivity than PCR but easy to perform and easy to read within 5 minute.

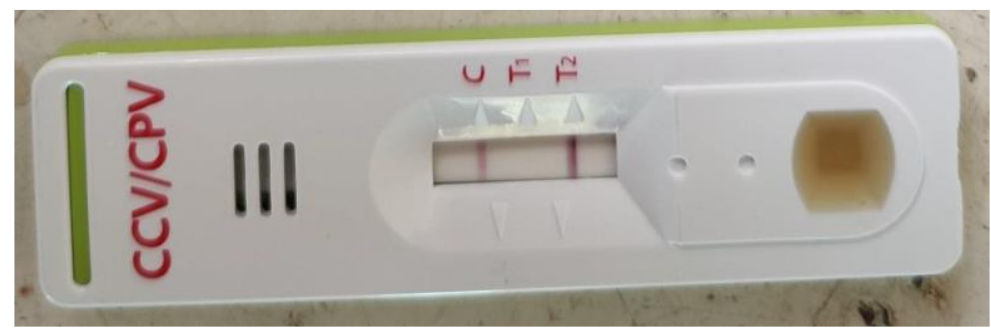

Fig1: Rapid Immunochromatographic strip test (ICT) for CPV2 antigen in feces. Positive reaction of sample

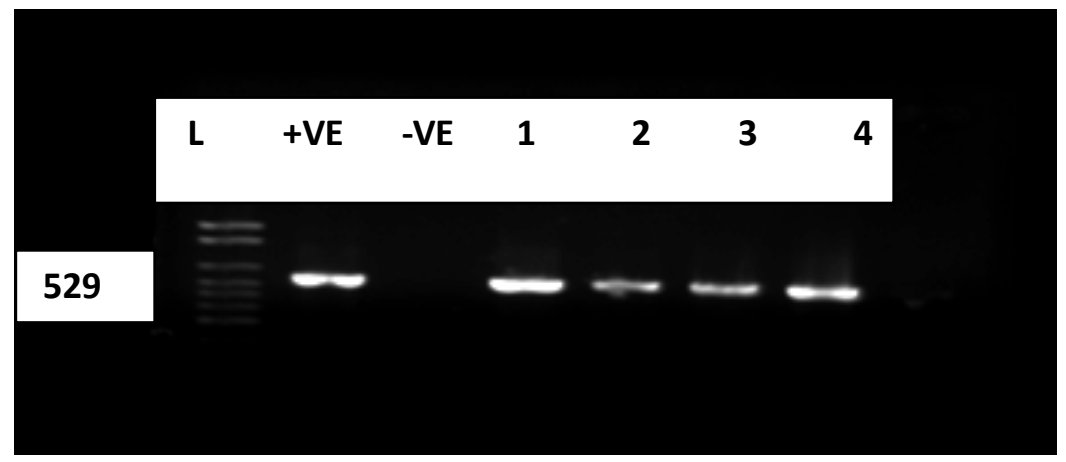

Figure (2) PCR product in Agarose gel electrophoresis at $529 \mathrm{bp}$.

Table (1): Percentage of agreement of rapid Immune chromatographic test (ICT) to PCR for diagnosis CPV2 in dog fecal samples according to localities.

\begin{tabular}{|c|c|c|c|c|c|}
\hline \multirow{2}{*}{ Province } & \multirow{2}{*}{$\begin{array}{c}\text { Total no } \\
\text { of } \\
\text { diseased } \\
\text { dogs }\end{array}$} & \multicolumn{2}{|c|}{ Rapid ICT } & \multicolumn{2}{|c|}{ PCR } \\
\hline & & $\begin{array}{l}\text { No of } \\
\text { positive } \\
\text { sample }\end{array}$ & $\%$ & $\begin{array}{c}\text { No of } \\
\text { positive } \\
\text { sample }\end{array}$ & $\%$ \\
\hline Ismailia & 30 & 10 & 33.3 & 18 & 60 \\
\hline Tanta & 30 & 15 & 50 & 29 & 96.7 \\
\hline E behaira & 40 & 20 & 50 & 39 & 97.5 \\
\hline Total & 100 & 45 & 45 & 86 & 86 \\
\hline
\end{tabular}


Discussion:

Canine parvovirus infection is one of the most important destructive enteric viral diseases of young puppies leading to high morbidity and mortality rates in unvaccinated puppies as well as in untreated infected dogs (Decaro et al., 2006).

However, the course of illness is also highly variable depending on the infectious dose, strain of the virus and $70 \%$ of infected animals die due to acute heart failure and shock, and the presence of undercurrent disease problems (Uddab et al., 2020).

In the current study, rapid immune-assay and PCR was compared (table 2). PCR test showed higher results than rapid immunoassay similar results obtained by (Desario et al., 2005).

Other reports stated that rapid chromatographic immunoassay is the most commonly diagnostic test for its simplicity and easy to perform with rapid interpretation within 5-10 minutes (Esfandiari and Klingeborn, 2000).

In a previous study the Immunochromatographic results were evaluated in comparison with ELISA in which Immunochromatographic

revealed an overall sensitivity References

Amthal .A. F. (2014): Molecular characterization of and specificity of $95.8 \%$ and 99.7\% (Esfandiari and Klingeborn, 2000), When real time PCR results were compared to Immunochromatographic test, results of real time PCR revealed an overall sensitivity and specificity of $56.1 \%$ and 100\% (Desario et al., 2005).

With respect to using of conventional PCR for amplification of VP-2 of CPV-2 in 100 fecal samples, 86 fecal samples give a predicted band when electrophoresed in agrose gel using a specific CPV-2 primer. VP2 gene is the most important part as it encodes the capsid protein responsible for viral antigenicity and pathogenicity of the canine parvovirus. Moreover the mutations in the VP2 gene were responsible for evolution of canine parvovirus (Ikeda et al., 2000; Truyen, 2006). Similar studies around the world targeted the same fragment of the VP2 gene for detection of canine parvovirus in feces and studying its evolution as (Senda et al., 1995; Buonavoglia et al., 2001) and in Egypt were (Amthal .A. F., 2014, Soliman et al., 2018 and Mohammed et al., 2019).

Canine Parvovirus-2 in Egypt. Ms. V. Sc. Thesis, virology department, Faculty of 
veterinary medicine, Cairo University.

Appel, M.J., Cooper, B.J., Greisen, H., Scott, $F$ and Carmichael, L.E. (1979a): Canine viral enteritis. I. Status report on corona- and parvo-like viral enteritides. The Cornell veterinarian $69,123-133$

Appel, M. J., Scott, F. W., and Carmichael, L. E. (1979b): Isolation and immunization studies of a canine parvo-like virus from dogs with Hemorrhagic enteritis. Vet Rec, 10(8) 5,156-159.

Buonavoglia, C., Martella, V., Pratelli, A., Tempesta, M., Cavalli, A., Buonavoglia, D., Bozzo, G., Elia, G., Decaro, N., and Carmichael, L. (2001): Evidence for evolution of canine parvovirus type 2 in Italy. The Journal of general virology 82, 3021-3025.

B urtonboy, G., Coignoul, F., Delferriere, N.,and Pastoret, P.P. (1979): Canine hemorrhagic enteritis: detection of viral particles by electron microscopy. Arch. Virol 61, 111.

De la Torre D, Mafla E, Puga B, Erazo L, Astolfi-Ferre ira C, Ferreira AP (2018). Molecular characterization of canine parvovirus variants (CPV-2a, CPV-2b, and CPV-2c) based on the VP2 gene in affected domestic dogs in Ecuador, Veterinary World, 11(4): 480-487.

Decaro, N., Campolo, M., Desario, C., Elia, G., Martella, V., Lorusso, E., and Buonavoglia, C. (2005): Maternally-derived antibodies in pups and protection from canine parvovirus infection. Biologicals : journal of the International Association of Biological Standardization 33, 261-267.

Decaro, N., Elia, G., Desario, C., Roperto, S., Martella, V., Campolo, M., Lorusso, A., Cavalli, A., and Buonavoglia, C (2006a): A minor groove binder probe real-time PCR assay for discrimination between type 2-based vaccines and field strains of canine parvovirus. Journal of virological methods 136, 65-70.

Desario, C., Decaro, N., Campolo, M., Cavalli, A., Cirone, F., Elia, G., Martella, V., Lorusso, E., Camero, M.,and Buonavoglia, C. (2005): Canine parvovirus infection: which diagnostic test for virus? Journal of virological methods 126, 179-185.

Esfandiari, J.,and

Klingeborn, B. ( 2000): A comparative study of a new rapid and one-step test for the detection of parvovirus in faeces from dogs, cats and mink. Journal of veterinary medicine. 
B, Infectious diseases and veterinary public health 47,145 153.

Funmilayo D. O (2020): Literature review on canine parvoviral enteritis variants in Nigeria. J Dairy Vet Anim Res; 9(1):26-32, Volume 9 Issue 1.

Ikeda, Y., Mochizuki, M., Naito, R., Nakamura, K., Miyazawa, T., Mikami, T., and Takahashi, E. (2000): Predominance of canine parvovirus (CPV) in unvaccinated cat populations and emergence of new antigenic types of CPVs in cats. Virology 278, 13-19.

Kramer, J.M., Me unier, P.C., Pollock, R.V. (1980): Canine parvovirus: update. Veterinary medicine, small animal clinician : VM, SAC 75, 1541-1555.

\section{McMaster GK, Tratschin JD} and Siegl G. (1981): Comparison of canine parvovirus with mink enteritis virus by restriction site mapping. J Virol 38: 368-37t.

Mohammed N, Ahmed $\mathbf{Z}$, Mohamed A, Ahmed E, Akram S, Ahmed K, Walid M, Mohamed H, Yassien $B$ and Hend A. (2019): Genetic and Molecular Typing of Canine Parvovirus Strains Circulating in Symptomatic Dogs in Egypt. Journal of Current Veterinary Research, Volume (1).
Parrish, C.R., Aquadro, C.F, and Carmichael, L.E. (1988): Canine host range and a specific epitope map along with variant sequences in the capsid protein gene of canine parvovirus and related feline, mink, and raccoon parvoviruses. Virology 166, 293-307.

Parrish, C.R. (1991): Mapping specific functions in the capsid structure of canine parvovirus and feline panleukopenia virus using infectious plasmid clones. Virology 183, 195-205.

Reed, A.P., Jones, E.V.,and Miller, T.J. (1988): Nucleotide sequence and genome organization of canine parvovirus. Journal of virology 62, 266-276.

Senda, M., Parrish, C.R., Harasawa, R., Gamoh, K., Muramatsu, M., Hirayama, N., Itoh, O. (1995b): Detection by PCR of wild-type canine parvovirus which contaminates dog vaccines. Journal of clinical microbiology 33, 110-113.

Soliman, R. M., Baker, N. M., Nasr, M. Y., and Khodeir, M. H. (2018): Clinical, virological and molecular characterization of canine parvo virus in dogs. European journal of pharmaceutical and medical research, 5(4), 525-535.

Truyen, U., (2006): Evolution of canine parvovirus--a need for 
new vaccines? Veterinary microbiology 117, 9-13.

Uddab P, Umesh D, and Arjun A. (2020): Canine parvovirus infection in young German shepherd dog: A Case Report. International Journal of Scientific and Research
Publications, Volume 10, Issue 3, March 2020655 ISSN 22503153.

Wills, C.G. (1952) Notes on infectious enteritis of mink and its relationship to feline enteritis. Can. J. Comp. Med, 16:419-420.

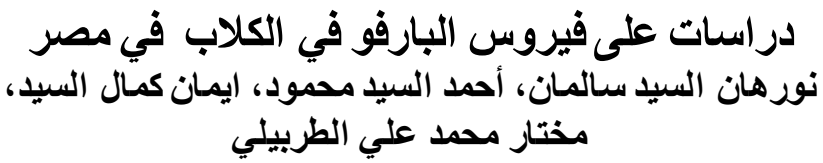

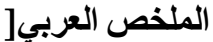

فبروس البارفو في الكلاب من اهم مسببات امر اض الكلاب انتشار ا و اشندها ضراوة وتأثنير ا علي التي

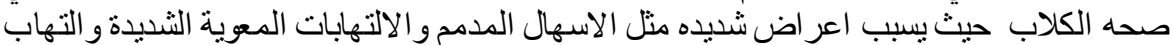

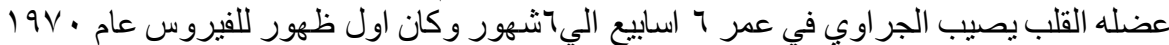

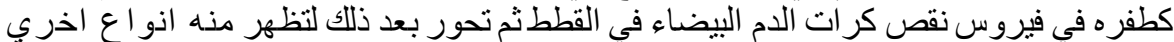

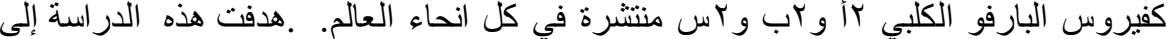
التفريق بين سلالات فيروس البارفو في الكلاب من حيث التتميط الجيني لهذه السلالات في ثلاث التاث

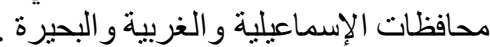

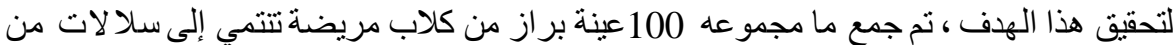

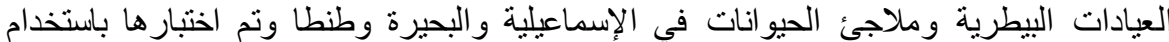

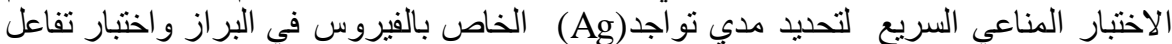

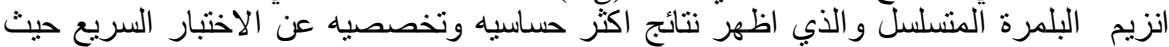

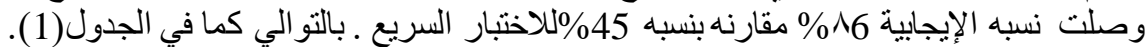

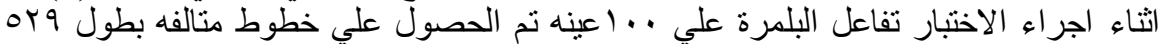

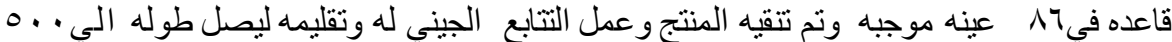
قاعده و ألثاملة الجز 